\title{
Alberts emphasizes education as nominee to head NAS
}

Washington. With one foot in the laboratory and the other in an elementary school classroom, biochemist Bruce Alberts is ready to take a cross-country leap into the presidency of the National Academy of Sciences.

Alberts, an American Cancer Society research professor at the University of California, San Francisco (UCSF), has been nominated by the academy's governing Council to succeed Frank Press, who is stepping down in July at the end of his second five-year term. There will be a postal vote in December by the academy's 1,640 members and no other names have been put forward by the council.

If elected, Alberts will end the academy's recent tradition of being led by a well-known science administrator. (Press was science adviser to President Jimmy Carter, and his predecessor, Frederick Seitz, was president of the Rockefeller University.) "They said that they wanted a working scientist", Alberts says of the nominating committee that pursued him for several months. "And they told me that I could still do science, if not at the bench, then at least by writing review articles and working on the third edition of my textbook [The Molecular Biology of the Cell, first published in 1983]".

The 54-year-old Alberts has been a pioneer in studying DNA replication through his work on bacteriophage T4, and he remains active in that area and in studying cell differentiation in the cytoskeleton. He directs a 12-person laboratory that receives substantial funding from the US National Institutes of Health, and he has reluctantly decided to close the laboratory over the next two years because of the impossibility of trying to run it from a distance of 3,000 miles. But he does not rule out a return.

"Running a lab is a full-time job", he says. "So I guess that I'll be doing this [serving as NAS president] for a while rather than trying to cure cancer. But right now my preference is to serve one term and come back out here. I love San Francisco, and I'm not going to sell my house. I don't plan on becoming a Washington type."

Equally important to Alberts as his science are his efforts to improve the quality of science education in US elementary and secondary schools. He is heavily involved in a programme within the San Francisco public schools, and he has written extensively about the need for scientists to help public school teachers to rekindle a sense of wonder in children about how the world works. Alberts says he accepted the NAS nomination only after deciding he could make a contribution in Washington.

"Leadership in science matters", he says. "Frank Press has been moving the academy in the right direction, but [science education] needs much more attention than it gets from the community. We need to motivate people and give them incentives to get involved. There's a lot of goodwill and idealism out there, but you need to show people how they can make a difference."

Last December, Alberts helped to organize a two-day workshop before the annual meeting of the American Society for Cell Biology for scientists and public school teach-

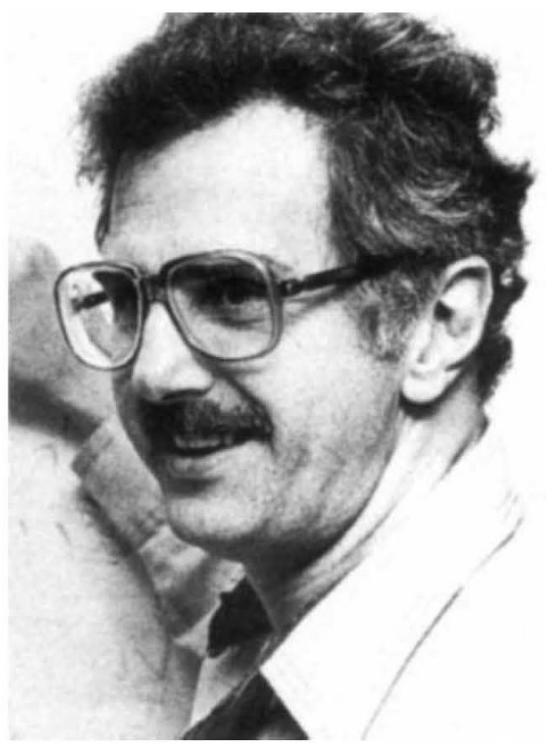

Alberts is leaving his heart in San Francisco.

ers; "I was at UCSF for ten years before I met a high school science teacher", he confesses. But public schools need more than moral support: they also need materials, time and continuing access to the latest scientific information, and Alberts hopes to raise the money to make those things possible.

The president of the National Academy of Sciences wears many hats, including that of fund-raiser, public spokesman for the scientific community and source of impartial information for the federal government. Alberts knows that he is less experienced in those areas than some of his predecessors, but he is not fazed by the challenge.

"Nobody has enough knowledge to take this job," he says. "But the academy is more than one person, and there are a lot of people who can help me to do mine."

Jeffrey Mervis

\section{OST rows with tide in report on intellectual property}

London. The first report by the British government's new Office of Science and Technology (OST) emphasizes the importance of finding applications for whatever research the government is willing to sponsor. Both the topic - intellectual property rights from publicly funded research - and the recommendations of the report reinforce the belief of the science minister, William Waldegrave, that because there will be no new money next year for British science, any changes must be self-supporting.

The report* is the first to be produced by the Office of Science and Technology (OST), created after April's general election. The office is responsible for producing a white paper (policy document) next year on science.

Most interesting as an indicator for the future is the report's concern with changing the scientific culture. It says that students should be made aware of issues relating to intellectual property and that its exploitation should be part of the rewards and incentives for scientists.

In many instances, the report reflects what is already going on. For example, the Medical Research Council (MRC) has a system widely admired for distributing the material rewards of intellectual property to the individual, the institution and the council, and it has also encouraged the recognition of patents in assessing achievement. The Agricultural and Food Research Council is in the process of adopting a similar reward system. By sanctioning such trends, the OST has assured its report a warm welcome and increased the chances that what it recommends will come to pass.

How useful this approach will be when the government wants to make changes that go against the grain remains to be seen. One of its more contentious proposals is for research councils to give greater weight in assessing research proposals to innovative applications of existing knowledge.

"The government wants to be seen to be even-handed, and it thinks that if it could just hit on the right magic formula, that would be applicable across the science base. But the process does not work the same way in every area," says David Owen, the MRC's director of industrial collaboration and licensing. Pharmaceutical companies, the chief market for the MRC's intellectual property, feel they are better placed to carry out commercial innovation using existing knowledge and instead look to the MRC for basic research. "We are good at one, they are good at the other", he says. Ian Mundell

* Intellectual property in the public sector research base ( $£ 10.50$ from HMSO, PO Box 276, London SW8 5DT, tel. 071-873-9090). 